\title{
Use of Olive-Mill Wastewater for the Containment of Phelipanche ramosa in Open Field of Processing Tomato Crop
}

\author{
Francesco Lops, Antonia Carlucci, Laura Frabboni, Annalisa Tarantino, and Grazia Disciglio
}

\begin{abstract}
Phelipanche ramosa (L.) Pomel is a root holoparasitic weed that infested many crops, particularly the processing tomato. In semi-arid regions of the world, this problem is increasing, both in intensity and in acreages. In the last few years, researches for the control of this parasite has increased its effort to use suitable methods, as well as the utilization of natural compounds. In this regard, four experimental trials were carried out over three growing seasons (2014, 2016 and 2017), at Foggia (Apulia Region, Southern Italy), in the open field, on processing tomato (cv. "Dres") crop, infested by $P$. ramosa, where the olive-mill wastewater (OMW) was incorporated into the soil at the dose of $80 \mathrm{~m} 3 \mathrm{ha}-140$ days prior to tomato seedling transplant in comparison with the untreated control. The numbers of $P$. ramosa emerged shoots (branched plants) were significantly lower in the OMW treatment than in the untreated control. The tomato marketable yield showed a significantly higher value in the OMW treatment than the untreated control. No significant differences for the fruit qualitative characteristics were observed.
\end{abstract}

Index Terms-Phelipanche ramosa, olive-mill wastewater, tomato crop, control, sustainable methods, parasitic.

\section{INTRODUCTION}

Apulia Region, a coastal area of southeastern Italy, is the most important agricultural area for processing tomato (Lycopersicon esculentum Mill.) crop, with the annual 17920 hectares, 90\% of which are in Foggia province [1]. In this area, in the last years, the tomato crop has been increasingly infested by the obligate root holoparasite plants of Phelipanche ramosa (L.) Pomel (syn. Orobanche ramosa L.) that is also continuously expanding into new areas. This parasitic species attaches to tomato roots early in the growing season, at 14-28 days after transplanting (DAT), depending on temperature and wet soil condition. The $P$. ramosa branched plant, composed of shoot numbers between 2 and 30, emerge from the soil between 35 and 56 DAT [2], [3]. They cause great yield reduction, ranging from 5 to $100 \%$, depending on the timing and severity of the infestation [4], [5]. The heavy infestations is due to the high production of seed number per plant (up to 500,000) [6] that have very small dimensions (about $0.2-0.3 \mathrm{~mm}$ ) and that in the absence of a host can remain viable in the soil for extended periods (up to 20 years) [7]. The parasitized tomato plants initially

Manuscript received April19, 2020; revised June 9, 2021.

The authors are with the Department of Agricultural Food and Environmental Science, University of Foggia, Italy (corresponding author: Grazia Disciglio; e-mail: grazia.disciglio@unifg.it). show some stunted growth, and subsequently a decrease in the quantity and quality of the yield, because of the reduced ability to use nutrients and water removed from the parasitic plant.

Various methods have been tried to maintain the P. ramosa populations below the threshold levels for damage, including preventive measures, physical, chemical, agronomic, biological, biotechnological and integrated methods [8]-[10].

In agricultural systems, characterized by low external input, herbicides are largely or entirely avoided, and weeds are suppressed largely through physical and ecological strategies [11]. Therefore, many researches to control the parasitic weed paid attention towards suitable methods, such as the use of organic compounds [10], [12]-[14]. Soil fertility plays a key role in $P$. ramosa management. Indeed, it is long been recognized that $P$. ramosa infestation tends to be associated with less a fertile soil condition [15]. The phenomenon is due to increase in the biosynthesis of strigolactones and in the release of parasite germination stimulants from plant roots that suffer from nutritional deficiencies [16]. On the contrary, the availability of nutrients in the soil usually promotes less development of the radical system, decreasing the likelihood of root recognition by parasitic seeds [17]. In addition, fertile soil improves the nutrient status of the host plants, allowing them to maintain a high osmotic potential and enhancing the competitive ability for sap flux versus parasitic demand [18]. Improved soil fertility, by adding organic matter, was found to be a potential control of Pheliphanche species [19]. Organic compounds are widely used in cropping systems to increase soil organic matter, structural stability, water holding and cation exchange capacities, and as a source of nutrients [20]. In addition, organic soil amendments can also provide a rich source of plant disease suppressive microorganisms and then large populations and high diversity with biological control potential [21]. Recently, the use of olive-mill wastewater (OMW), as suitable method to contain the P. ramosa, has been proposed [22].

In this regard in Italy, the Apulia is the most important region of olive oil production $\left(200,000 \mathrm{t} \mathrm{year}^{-1}\right)$, which extraction process from olive fruit (i.e. without preliminary treatments) produces a large quantity of OMW. This wastewater, derived mainly from the centrifuge extraction method, can be applied to the soil for agronomical use at the maximum amount of $80 \mathrm{~m}^{3} \mathrm{ha}^{-1}$ [23].

The OMW availability is restricted to November-March period, when the fields are mainly cultivated with cereal crops or are in pre-sown fallow before the spring crops. 
Therefore, for the spring-summer crops such as tomato, applied OMW must be made 35-40 days before planting, without contraindications [24], [25].

The OMW has chemical properties (i.e. organic carbon, potassium and phosphorus contents) that could increase soil fertility [26]. In addition, its content of phenolic compounds can act in the soil surface layer on the germination of the weed seed [27], [28] or suppress plant diseases and phytotoxicity [29], [30].

Considering very few information on the use of OMW for $P$. ramosa control, this study is mainly focused on wastewater application into the soil, before transplanting tomato crop in the field, to assess: I) whether this method is efficient about to $P$. ramosa containment; II) the effects on the quantitative and qualitative parameters of the tomato yield.

\section{MATERIAL AND MethodS}

\section{A. General Description of the Experimental Trials}

Four experimental trials were carried out in three years (2014, 2016 and 2017) at three different private farms, fairly close together, located in Foggia province $\left(41^{\circ} 65^{\prime} \mathrm{N}\right.$, $12^{\circ} 48^{\prime}$ E, altitude, $54 \mathrm{~m}$ a.s.1., Apulian Region, southern Italy) In this agricultural area, the infestation of $P$. ramosa is widely diffuse. The trials were carried in processing tomato crop, to assess the effect OMW on the control of $P$. ramosa in comparison with the untreated crop. In each trial, the OMW was incorporated into the soil at the dose and mode as reported in Table I.

TABLE I: COMPOSITION AND APPLICATION MODE OF THE OMW USED IN THE EXPERIMENTS

\begin{tabular}{|c|c|c|}
\hline Treatment & Main characteristics & Application mode \\
\hline $\begin{array}{l}\text { Olive-mill } \\
\text { wastewater }\end{array}$ & $\begin{array}{l}\mathrm{pH}, 5.23 \text {; dry matter, } 62.0 \text { (g } \\
\left.\mathrm{L}^{-1}\right) \text {; total nitrogen, } 1.6 \\
\left(\mathrm{Kjeldhal}, \mathrm{g} \mathrm{L}^{-1}\right) \text {; phosphorus, } \\
185\left(\mathrm{P}_{2} \mathrm{O}_{5}, \mathrm{mg} \mathrm{L}^{-1}\right) \text {; potassium, } \\
1044\left(\mathrm{~K}_{2} \mathrm{O} ; \mathrm{g} \mathrm{L}^{-1}\right) \text {; total organic } \\
\text { carbon, } 43.3\left(\mathrm{~g} \mathrm{~L}^{-1}\right) \text {; sodium, } 36 \\
\left(\mathrm{mg} \mathrm{L}^{-1}\right) \text {; calcium, } 69\left(\mathrm{mg} \mathrm{L}^{-1}\right) ; \\
\text { magnesium, } 90\left(\mathrm{mg} \mathrm{L}^{-1}\right) ; \text { iron, } \\
14\left(\mathrm{mg} \mathrm{L}^{-1}\right) \text {, total phenols, } 2.7(\mathrm{~g} \\
\left.\mathrm{L}^{-1}\right) ; \text { Biochemical oxygen } \\
\text { demand (BOD), } 28.7\left(\mathrm{~g} \mathrm{O} \mathrm{L}^{-1}\right) \text {; } \\
\text { Chemical oxygen demand } \\
(\mathrm{COD}), 85.7\left(\mathrm{~g} \mathrm{O} \mathrm{L}^{-1}\right) \text {. }\end{array}$ & $\begin{array}{l}\text { Applied into the soil } 40 \\
\text { days before the tomato } \\
\text { seedling } \\
\text { transplantation, at } 80 \\
\mathrm{~m}^{3} \text { ha }^{-1} \text {. This is the } \\
\text { maximum amount } \\
\text { permitted to be used in } \\
\text { the fields on capable } \\
\text { soil (in agreement with } \\
\text { Italian Law No } 574 \text {, } \\
\text { 1996). }\end{array}$ \\
\hline
\end{tabular}

The experimental sites were in a typical semi-arid zone, characterized by a Mediterranean climate, with a mild winter and dry-warm summer. According to the long-term climatic data, the annual rainfall and the mean temperature are 526 $\mathrm{mm}$ and $10.9^{\circ} \mathrm{C}$, respectively [31].

In table II, meteorological data (mean monthly maximum, minimum temperature, and total rainfall) are reported. They were collected during the experimental years at the nearest meteorological station, few kilometers from the experimental site and supplied by the "Consorzio per la Bonifica della Capitanata".

In all the experimental trials, the tomato crop (cv. "Dres") was transplanted in open fields in double rows $200 \mathrm{~cm}$ apart, with $40 \mathrm{~cm}$ spacing between the paired rows and $30 \mathrm{~cm}$ spacing in each row, resulting in a theoretical plant density of 3.3 plants $\mathrm{m}^{-2}$. A randomized block design with three replicates (i.e. plots) for the OMW treatment and control was adopted. Each plot was $20 \mathrm{~m}^{2}(2 \mathrm{~m} \times 10 \mathrm{~m})$ separated by two double rows (4 $\mathrm{m}$ distance) of tomato seedling that were not included in these experimental treatments. Drip irrigation method was used with the drip lines placed between each pair of plant rows. The water volume at each irrigation varied from $100 \mathrm{~m}^{3} \mathrm{ha}^{-1}$ to $300 \mathrm{~m}^{3} \mathrm{ha}^{-1}$, depending on the crop growth stage, with a watering interval of about 3-4 days. The agricultural management practices applied to tomato crop during the experimental trials were those commonly adopted by local farmers, such as for fertilizing and for weed and pest control.

TABLE II: MEAN Monthly MAXimum, Minimum AIR TemPeRATURE AND TOTAL PRECIPITATION RECORDED DURING THE EXPERIMENTAL YEARS

\begin{tabular}{|c|c|c|c|c|}
\hline \multirow[t]{2}{*}{ Characteristics } & & \multicolumn{3}{|c|}{ Field } \\
\hline & & 'Ortuso' & 'Pazienza' & 'Futuragri \\
\hline $\begin{array}{l}\text { Sand }[2.0>\varnothing< \\
0.02 \mathrm{~mm}]\end{array}$ & $(\%)$ & 34.68 & 47.20 & 45.61 \\
\hline $\begin{array}{l}\text { Loam }[0.02>\varnothing \\
<0.002 \mathrm{~mm}]\end{array}$ & $(\%)$ & 31.54 & 32.39 & 20.00 \\
\hline $\begin{array}{l}\text { Clay }[\varnothing<0.002 \\
\mathrm{mm}]\end{array}$ & $(\%)$ & 33.78 & 20.40 & 24.41 \\
\hline $\begin{array}{l}\text { Typology } \\
\text { (USDA) }\end{array}$ & & Clay-Loam & $\begin{array}{l}\text { Medium } \\
\text { texture }\end{array}$ & $\begin{array}{l}\text { Medium } \\
\text { texture }\end{array}$ \\
\hline $\begin{array}{l}\text { Organic matter } \\
\text { (Walkley-Black) }\end{array}$ & $(\%)$ & 1.3 & 2.3 & 1.3 \\
\hline $\mathrm{pH}\left(\right.$ in $\left.\mathrm{H}_{2} \mathrm{O}\right)$ & & 8.7 & 8.4 & 8.1 \\
\hline $\begin{array}{l}\text { ECe on } 1: 2 \\
\text { (W/v) (aqueous } \\
\text { soil extract) }\end{array}$ & $\begin{array}{l}(\mathrm{dS} \\
\left.\mathrm{cm}^{-1}\right)\end{array}$ & 0.2 & 0.3 & 0.5 \\
\hline $\begin{array}{l}\text { Total nitrogen } \\
\text { (Kjeldhal) }\end{array}$ & $(\%)$ & 1.4 & 1.1 & 0.9 \\
\hline $\begin{array}{l}\mathrm{P}_{2} \mathrm{O}_{5} \text { available } \\
\text { (Olsen) }\end{array}$ & $\begin{array}{l}\text { (mg } \\
\mathrm{kg})\end{array}$ & 47 & 65 & 86 \\
\hline $\begin{array}{l}\mathrm{K}_{2} \mathrm{O} \\
\text { exchangeable } \\
\text { (Shollemberger) }\end{array}$ & $\begin{array}{l}(\mathrm{mg} \\
\mathrm{kg})\end{array}$ & 1470 & 1380 & 1430 \\
\hline
\end{tabular}

\section{B. Sampling and Measurements}

In each tomato growth cycle, at different day after transplant (DAT), the branched shoots of $P$. ramosa (hereafter referred to as 'shoots') emerged from the soil were counted on sampling area of $4 \mathrm{~m}^{2}$ for each plot. Given the high uniform of the density of tomato plants per $\mathrm{m} 2$ in all experiments, the number of emerged shoots per unit of surface area can be considered an adequate method to estimate the parasite infection. The tomato fruit were harvested in the same sampling area at full-maturity stage. At harvesting, the marketable yield was determined. Moreover, for a sample of 10 marketable tomato fruit from each plot, the following qualitative parameters were measured: mean weight (g), dry-matter content ( $\%$ fruit fresh matter); soluble solids content $\left({ }^{\circ} \mathrm{Brix}\right) ; \mathrm{pH}$ and titratable acidity ( $\mathrm{g}$ citric acid per $100 \mathrm{~mL}$ fresh fruit juice) [32]. Fruit color were recorded in the CIELab system, using a Minolta CR-400 colorimeter (Konica Minolta Sensing, Inc., Japan). In the CIELab colour space, $\mathrm{L}^{*}$ indicates the brightness, $\mathrm{a}^{*}$ ranges from green $\left(-\mathrm{a}^{*}\right)$ to red $\left(+a^{*}\right)$, and $b^{*}$ varies from blue $\left(-b^{*}\right)$ to yellow $\left(+b^{*}\right)$ [33], [34].

All the data were subjected to analysis of variance 
(ANOVA), using the JMP software (SAS Institute Inc. Cary, NC, USA) and the means were compared by Tukey's test at $5 \%$ probability.

In Table III, the particular description of each experimental trial is reported. In particular, as for the monitoring dates of $P$. ramosa emerged shoots in the fields, they were generally related to the following tomato phonological phases: initial fruit set, complete fruit set, initial fruit ripening and harvesting time. In table IV, the main physic-chemical characteristics of the soils of the experimental fields are reported.

TABLE III: PARTICULAR DESCRIPTION OF THE TRIALS

\begin{tabular}{|c|c|c|c|c|c|}
\hline \multirow[t]{2}{*}{ Trial } & \multirow[t]{2}{*}{ Year } & \multirow{2}{*}{$\begin{array}{l}\text { Private } \\
\text { Farm }\end{array}$} & \multicolumn{3}{|c|}{ Data } \\
\hline & & & Trasplanting & Harvest & $\begin{array}{l}\text { Data of } \\
P . \\
\text { ramosa } \\
\text { surveys }\end{array}$ \\
\hline 1 & $\begin{array}{l}201 \\
4\end{array}$ & 'Ortuso' & May 5 & August 18 & $\begin{array}{l}56,78, \\
81 \text { and } \\
92\end{array}$ \\
\hline 2 & $\begin{array}{l}201 \\
6\end{array}$ & 'Pazienza' & May 15 & August 18 & $\begin{array}{l}74, \\
81,93 \\
\text { and } 103\end{array}$ \\
\hline 3 & $\begin{array}{l}201 \\
6\end{array}$ & 'Futuragri' & May 19 & $\begin{array}{l}\text { September } \\
13\end{array}$ & $\begin{array}{l}56,63, \\
75 \text { and } \\
116\end{array}$ \\
\hline 4 & $\begin{array}{l}201 \\
7\end{array}$ & 'Pazienza' & April 10 & July 20 & $\begin{array}{l}60,70, \\
80 \text { and } \\
92\end{array}$ \\
\hline
\end{tabular}

TABLE IV: PHYSIC-CHEMICAL CHARACTERISTICS OF THE SOILS OF THE THREE EXPERIMENTAL FIELD

\begin{tabular}{|c|c|c|c|c|}
\hline \multirow[t]{2}{*}{ Chaacteristics } & & \multicolumn{3}{|c|}{ Field } \\
\hline & & 'Ortuso' & 'Pazienza' & 'Futuragri' \\
\hline $\begin{array}{l}\text { Sand }[2.0>\varnothing< \\
0.02 \mathrm{~mm}]\end{array}$ & $(\%)$ & 34.68 & 47.20 & 45.61 \\
\hline $\begin{array}{l}\operatorname{Loam}[0.02>\varnothing \\
<0.002 \mathrm{~mm}]\end{array}$ & $(\%)$ & 31.54 & 32.39 & 20.00 \\
\hline $\begin{array}{l}\text { Clay }[\varnothing<0.002 \\
\mathrm{mm}]\end{array}$ & $(\%)$ & 33.78 & 20.40 & 24.41 \\
\hline $\begin{array}{l}\text { Typology } \\
\text { (USDA) }\end{array}$ & & Clay-Loam & $\begin{array}{l}\text { Medium } \\
\text { texture }\end{array}$ & $\begin{array}{l}\text { Medium } \\
\text { texture }\end{array}$ \\
\hline $\begin{array}{l}\text { Organic matter } \\
\text { (Walkley-Black) }\end{array}$ & $(\%)$ & 1.3 & 2.3 & 1.3 \\
\hline $\mathrm{pH}\left(\right.$ in $\left.\mathrm{H}_{2} \mathrm{O}\right)$ & & 8.7 & 8.4 & 8.1 \\
\hline $\begin{array}{l}\text { ECe on } 1: 2 \\
(\mathrm{~W} / \mathrm{v}) \text { (aqueous } \\
\text { soil extract) }\end{array}$ & $\begin{array}{l}(\mathrm{dS} \\
\left.\mathrm{cm}^{-1}\right)\end{array}$ & 0.2 & 0.3 & 0.5 \\
\hline $\begin{array}{l}\text { Total nitrogen } \\
\text { (Kjeldhal) }\end{array}$ & $(\%)$ & 1.4 & 1.1 & 0.9 \\
\hline $\begin{array}{l}\mathrm{P}_{2} \mathrm{O}_{5} \text { available } \\
\text { (Olsen) }\end{array}$ & $\begin{array}{l}(\mathrm{mg} \\
\mathrm{kg})\end{array}$ & 47 & 65 & 86 \\
\hline $\begin{array}{l}\mathrm{K}_{2} \mathrm{O} \\
\text { exchangeable } \\
\text { (Shollemberger) }\end{array}$ & $\begin{array}{l}(\mathrm{mg} \\
\mathrm{kg})\end{array}$ & 1470 & 1380 & 1430 \\
\hline
\end{tabular}

\section{RESULTS}

\section{A. P. ramosa Emerged Shoots}

In Fig. 1 are reported, for each treatment of the four trials, the number of emerged shoots per $\mathrm{m} 2$ at different DAT during the tomato crop cycles.

Trial 1. The $P$. ramosa shoots were detected at $56,78,81$ and 92 DAT. At 56 DAT a low infestation was observed in both OMW and control treatments. Later over time, the increase of infestation occurred particularly till 78 DAT, though with significant lower numbers of emerged shoots in the OMW treatment $\left(18.6 \mathrm{~m}^{-2}\right)$ compared to the control (28.6 $\mathrm{m}^{-2}$ ). Moreover, as reported also in Fig. 2, at the end of tomato cycle (92 DAT), the control showed a significant higher emerged shoots $\left(33.6 \mathrm{~m}^{-2}\right)$ compared to the OMW treatment $\left(20.3\right.$ shoots $\left.\mathrm{m}^{-2}\right)$, with a reduction in the last of $39.6 \%$ was measured.

Trial 2. In this trial the infestation of $P$. ramosa was monitored at 74, 81, 93 and 103 DAT. AT 74 DAT, the numbers of emerged shoots in the untreated control was already significantly higher $\left(4.4\right.$ shoots $\left.\mathrm{m}^{-2}\right)$ than in the OMW treatment $\left(1.0 \mathrm{~m}^{-2}\right)$. In the following days during the tomato cycle the greatest increase in the infestation was recorded up to 81 DAT in both treatments, although with a significant lower values in OMW $\left(15.3 \mathrm{~m}^{-2}\right)$ than the untreated ones $\left(40.1 \mathrm{~m}^{-2}\right)$. In the last part of the tomato cycle (from 81 DAT to 103 DAT) the shoot density was almost stable (Fig. 1).

Therefore, as reported also in Fig. 2, at the end of tomato cycle, in the OMW treatment a reduction of $62 \%$ of infestation was detected.

Trial 3. The P. ramosa shoots were detected at 56, 63, 75 and 116 DAT. At 56 DAT, a very low emerged shoots were observed, with no significant differences between the OMW treatment and the control. Afterward, through the tomato crop cycle, the emerged shoots slightly increased to 63 DAT and then increased later, with significant higher values in the control than the in OMW treatment. At the tomato harvest (116 DAT), as reported also in Fig. 2, 3.1 shoots $\mathrm{m}^{-2}$ were registered for the treated plots and $12.9 \mathrm{~m}-2$ for the untreated ones, with the reduction in the last of $76.0 \%$.

Trial 4. The $P$. ramosa emerged shoots were detected at 60 , 70, 80 and 91 DAT. At first survey (60 DAT), shoot density was already significantly higher in the untreated control (3.2 $\mathrm{m}^{-2}$ ) than in the OMW treatment $\left(1.1 \mathrm{~m}^{-2}\right)$. Subsequently, during the tomato growing cycle, the emerged shoots increased. At harvest (91 DAT), as reported also in Fig. 2, the untreated control showed 18.3 shoots $\mathrm{m}^{-2}$ against a lower value of 12.0 shoots $\mathrm{m}^{-2}$ in the OMW treatment, with the shoots reduction in the last of $34.4 \%$ (Fig. 1).

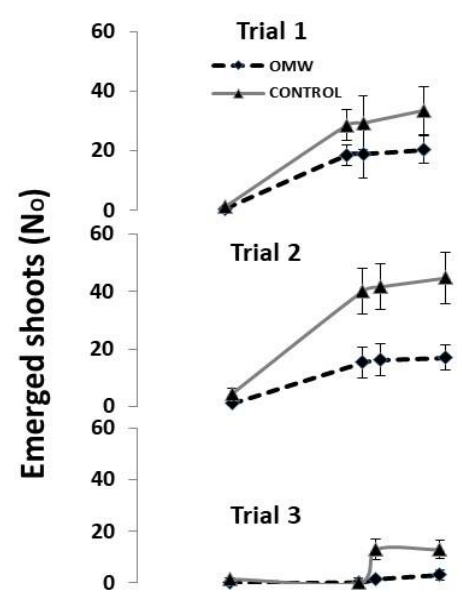

Fig. 1. Average number per $\mathrm{m}^{-2}$ of emerged shoots of $P$. ramosa for OMW and control at different days after transplanting (DAT) of processing tomato crop in the four trials. 
Moreover, the mean shoot values of all the trials, as average of each treatment at harvesting times, they were significantly lower in OMW $\left(13.1 \mathrm{~m}^{-2}\right)$ compared to the control $\left(27.3 \mathrm{~m}^{-2}\right)$.

Regarding the comparison among the four trials, as an average of treatments (Table V), significant differences of mean emerged shoot were noted.

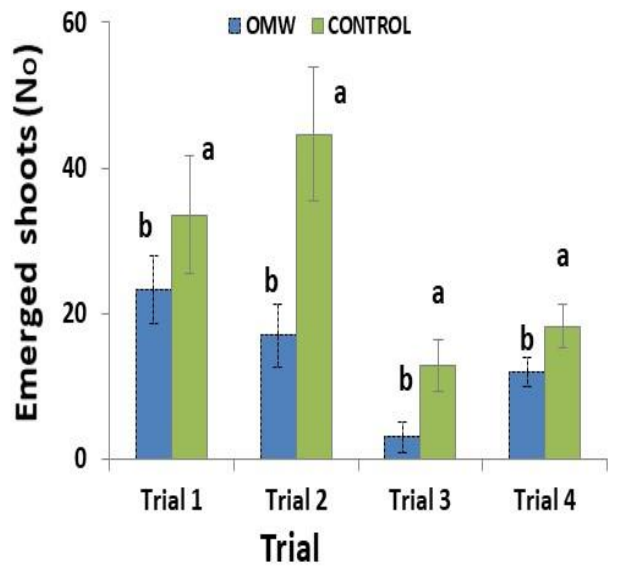

Fig. 2. Average number per $\mathrm{m}^{-2}$ of emerged shoots of $P$. ramosa for OMW and control at tomato harvesting in each trial.
TABLE V: AVERAGE Number PER $\mathrm{M}^{-2}$ OF P. RAMOSA EMERGED SHOOTS AT DIFFERENT DAYS AFTER TRANSPLANTING (DAT) OF PROCESSING TOMATO

\begin{tabular}{lllll}
\multicolumn{5}{c}{ CROP IN THE FOUR TRIALS (MEAN OF TREATMENTS) } \\
\hline \hline Trial 2014 & 56 DAT & 78 DAT & 81 DAT & $\begin{array}{l}\text { 92 } \\
\text { DAT(Harvest) }\end{array}$ \\
& $1.0 \pm 0.2 \mathrm{a}$ & $23.6 \pm 9.7 \mathrm{a}$ & $24.2 \pm 6.8 \mathrm{a}$ & $26.9 \pm 6.3 \mathrm{a}$ \\
Trial 2016 & $74 \mathrm{DAT}$ & $81 \mathrm{DAT}$ & $93 \mathrm{DAT}$ & $103 \mathrm{DAT}$ \\
& $2.7 \pm 1.2 \mathrm{a}$ & $27.2 \pm 6.6 \mathrm{a}$ & $29.8 \pm 6.7 \mathrm{a}$ & $30.8 \pm 6.7 \mathrm{a}$ \\
Trial 2016 & $56 \mathrm{DAT}$ & $63 \mathrm{DAT}$ & $75 \mathrm{DAT}$ & $116 \mathrm{DAT}$ \\
& $0.8 \pm 2.1 \mathrm{a}$ & $3.3 \pm 1.0 \mathrm{~b}$ & $7.2 \pm 2.2 \mathrm{~b}$ & $8.0 \pm 2.8 \mathrm{c}$ \\
& & & & \\
Trial 2017 & $60 \mathrm{DAT}$ & $70 \mathrm{DAT}$ & $80 \mathrm{DAT}$ & $91 \mathrm{DAT}$ \\
& $2.1 \pm 1.1 \mathrm{a}$ & $7.1 \pm 1.6 \mathrm{~b}$ & $13.7 \pm 1.0 \mathrm{~b}$ & $15.1 \pm 2.4 \mathrm{~b}$ \\
\hline \hline
\end{tabular}

Data are means \pm Standard Errors of 6 sample. Means followed by the same letters in each column are not significantly different $(P \leq 0.05$ Tukey's test).

\section{B. Yield and Qualitative Traits of Tomato Fruit}

Yield and qualitative traits of tomato fruit of each trial are reported in Table VI.

Trial 1 . The marketable yield was clearly affected by the $P$. ramosa infestation, since the control gave the lowest value $\left(55.5 \mathrm{t} \mathrm{ha}^{-1}\right)$ significantly different from OMW treatment $\left(67.7 \mathrm{t} \mathrm{ha}^{-1}\right)$. The fruit quality parameters, such as mean fruit weight, dry matter, color index, $\mathrm{pH}$ and soluble solids content were no significantly different between OMW treatment and the untreated control.

TABLE VI: YIELD AND QUALITY TRAITS OF TOMATO FRUIT UNDER DIFFERENT TREATMENTS FOR THE FOUR TRIALS

\begin{tabular}{|c|c|c|c|c|c|c|c|c|}
\hline Treatment & Marketable yield & \multicolumn{7}{|c|}{ Red fruit } \\
\hline Year & $\left(\mathbf{t ~ h a}^{-1}\right)$ & $\begin{array}{c}\text { Mean weight } \\
\text { (g) }\end{array}$ & $\begin{array}{c}\text { Dry matter } \\
\text { (g) }\end{array}$ & $\begin{array}{c}\text { Color coord. } \\
\text { L }\end{array}$ & $\begin{array}{c}\text { Color index } \\
(\mathbf{a} / \mathbf{b})\end{array}$ & $\begin{array}{c}\text { Sol. Solids } \\
{ }^{\circ} \text { Brix }\end{array}$ & pH & $\begin{array}{c}\text { Titr. Acidity } \\
\text { (TA g citric ac. } 100 \mathrm{ml}^{-1} \\
\text { of juice) }\end{array}$ \\
\hline OMW & $67.7 \pm 0.6 \mathrm{a}$ & $48.3 \pm 3.3$ & $7.3 \pm 0.1$ & $38.5 \pm 0.4$ & $1.1 \pm 0.2$ & $5.0 \pm 0.1$ & $4.1 \pm 0.7$ & $0.35 \pm 0.01$ \\
\hline Control & $55.5 \pm 10.9 \mathrm{~b}$ & $58.3 \pm 3.3$ & $6.5 \pm 0.2$ & $37.4 \pm 2.1$ & $1.0 \pm 0.2$ & $5.6 \pm 0.2$ & $4.1 \pm 0.2$ & $0.38 \pm 0.01$ \\
\hline Trial 2 & & & & & & & & \\
\hline OMW & $81.4 \pm 0.8 \mathrm{a}$ & $61.0 \pm 3.9$ & $5.3 \pm 0.2$ & $39.6 \pm 0,4$ & $1.1 \pm 0.1$ & $4.4 \pm 0.3$ & $4.6 \pm 0.2$ & $0.35 \pm 0.01$ \\
\hline Control & $74.9 \pm 1.3 \mathrm{~b}$ & $52.0 \pm 2.8$ & $6.1 \pm 0.3$ & $35.5 \pm 2.1$ & $1.1 \pm 0.1$ & $4.5 \pm 0.2$ & $4.5 \pm 0.1$ & $0.37 \pm 0.02$ \\
\hline Trial 3 & & & & & & & & \\
\hline OMW & $96.8 \pm 12.0 \mathrm{a}$ & $80.1 \pm 7.2$ & $6.6 \pm 0.4$ & $50.5 \pm 0.3$ & $1.1 \pm 0.1$ & $5.2 \pm 0.1$ & $4.8 \pm 0.1$ & $0.50 \pm 0.01$ \\
\hline Control & $69.4 \pm 2.3 \mathrm{~b}$ & $75.3 \pm 6.2$ & $6.5 \pm 0.2$ & $48.7 \pm 1.1$ & $1.1 \pm 0.1$ & $4.2 \pm 0.1$ & $4.4 \pm 0.1$ & $0.40 \pm 0.01$ \\
\hline Trial 4 & & & & & & & & \\
\hline OMW & $112.8 \pm 6.2 \mathrm{a}$ & $51.7 \pm 1.7$ & $6.6 \pm 0.2$ & $40.3 \pm 1.7$ & $1.1 \pm 0.1$ & $5.6 \pm 0.4$ & $4.3 \pm 0.1$ & $0.41 \pm 0.02$ \\
\hline Control & $101.3 \pm 7.1 \mathrm{~b}$ & $51.4 \pm 3.0$ & $6.1 \pm 0.4$ & $49.3 \pm 1.5$ & $1.2 \pm 0.1$ & $4.9 \pm 0.2$ & $4.4 \pm 0.1$ & $0.49 \pm 0.02$ \\
\hline OMW & $89.7 \pm 4.9 \mathrm{a}$ & $60.2 \pm 4.0$ & $5.7 \pm 0.2$ & $45.5 \pm 0.7$ & $1.1 \pm 0.1$ & $5.0 \pm 0.2$ & $4.4 \pm 0.3$ & $0.40 \pm 0.01$ \\
\hline Control & $75.3 \pm 5.4 \mathrm{~b}$ & $59.2 \pm 3.8$ & $6.3 \pm 0.3$ & $42.7 \pm 1.7$ & $1.1 \pm 0.1$ & $4.8 \pm 0.2$ & $4.3 \pm 0.1$ & $0.41 \pm 0.01$ \\
\hline Significance & ** & n.s. & n.s. & n.s. & n.s. & n.s & n.s & n.s. \\
\hline
\end{tabular}

Data are means \pm Standard Errors. Means followed by the same letters determined in each column are not significant by different $(P \leq 0.05$ Tukey’s test); n.s., not significant; **, significant.

TABLE VII: AVERAGE YIELD AND QUALITY TRAITS OF TOMATO FRUIT FOR THE DIFFERENT TRIALS

\begin{tabular}{|c|c|c|c|c|c|c|c|c|}
\hline \multirow{2}{*}{$\begin{array}{l}\text { Treatment } \\
\text { Year }\end{array}$} & \multirow{2}{*}{$\begin{array}{c}\text { Marketable yield } \\
\left(\mathrm{t} \mathrm{ha}^{-1}\right)\end{array}$} & \multicolumn{7}{|l|}{ Red fruit } \\
\hline & & $\begin{array}{l}\text { Mean } \\
\text { weight } \\
(\mathrm{g})\end{array}$ & $\begin{array}{l}\text { Dry } \\
\text { matter } \\
(\mathrm{g})\end{array}$ & $\begin{array}{r}\text { Color } \\
\text { coord. } \\
\text { L }\end{array}$ & $\begin{array}{l}\text { Color } \\
\text { index } \\
\qquad(\mathrm{a} / \mathrm{b})\end{array}$ & $\begin{array}{l}\text { Sol. } \\
\text { Solids } \\
\quad{ }^{\circ} \text { Brix }\end{array}$ & pH & $\begin{array}{l}\text { Titr. Acidity } \\
\text { (TA g citric ac. } 100 \mathrm{ml}^{-1} \text { of juice) }\end{array}$ \\
\hline & & \multicolumn{7}{|c|}{ Trial } \\
\hline Trial 1 & $61.1 \pm 5.7 \mathrm{c}$ & $53.3 \pm 3.3 \mathrm{~b}$ & $6.9 \pm 0.2$ & $39.7 \pm 1.2$ & $1.1 \pm 0.2$ & $5.3 \pm 0.1$ & $4.1 \pm 0.9$ & $0.36 \pm 0.01$ \\
\hline Trial 2 & $78.1 \pm 1.1 \mathrm{~b}$ & $56.5 \pm 3.3 \mathrm{~b}$ & $5.7 \pm 0.2$ & $37.5 \pm 1.2$ & $1.1 \pm 0.1$ & $4.4 \pm 0.2$ & $4.5 \pm 0.1$ & $0.36 \pm 0.01$ \\
\hline Trial 3 & $83.1 \pm 7.1 \mathrm{~b}$ & $77.7 \pm 6.7 \mathrm{a}$ & $6.5 \pm 0.3$ & $49.6 \pm 0.7$ & $1.1 \pm 0.1$ & $4.7 \pm 0.1$ & $4.6 \pm 0.1$ & $0.45 \pm 0.02$ \\
\hline \multirow[t]{2}{*}{ Trial 4} & $107.0 \pm 6.6 \mathrm{a}$ & $51.5 \pm 2.7 \mathrm{~b}$ & $6.3 \pm 0.3$ & $44.8 \pm 1.6$ & $1.1 \pm 0.3$ & $5.2 \pm 0.3$ & $4.3 \pm 0.1$ & $0.45 \pm 0.02$ \\
\hline & & \multicolumn{7}{|c|}{ Trial $\mathrm{x}$ treatment } \\
\hline
\end{tabular}

Data are means \pm Standard Errors. Means followed by the same letters determined in each column are not significant by different $(P \leq 0.05$ Tukey's test $)$ n.s., not significant. 
Trial 2. The marketable yield, because of the different parasite infestation, was significantly higher in the OMW treated crop $\left(81.4 \mathrm{t} \mathrm{ha}^{-1}\right)$ compared with the untreated one $\left(74.9 \mathrm{t} \mathrm{ha}^{-1}\right)$. Also, in this trial the main qualitative fruit characteristics were not significantly different between the OMW treatment and the control.

Trial 3. The productivity of the tomato crop was enhanced by OMW treatment $\left(96.8 \mathrm{t} \mathrm{ha}^{-1}\right)$ in contrast to untreated control (69.4 $\mathrm{t}$ ha-1). Even in this experiment, for the qualitative fruit characteristics, there were no significant differences between treatments.

Trial 4. The positive effect on marketable yield was obtained in OMW treated crop (112.8 $\mathrm{t} \mathrm{ha}^{-1}$ ) compared with untreated control $\left(101.3 \mathrm{t} \mathrm{ha}^{-1}\right)$. Also in this experiment, the main qualitative fruit characteristics were not significantly different between the OMW treatment and the control. As for the comparison among the trials (Tab. VII) the highest yield was obtained in the trial $4\left(107 \mathrm{t} \mathrm{ha}^{-1}\right)$, which differed significantly from the other ones (values ranged between 61.1 and $83.1 \mathrm{t} \mathrm{ha}^{-1}$ ). Regarding the main qualitative fruit characteristics, not significant differences were noted. Finally, neither of the trial factors considered (trial, treatment) showed any significant effects in their interactions (Tab. VII).

Moreover, the relationship between tomato marketable yield of the several trial and $P$ ramosa infestation at harvesting time is such that the smaller numbers of emerged shoots for the OMW treatment resulted in increase marketable yield. In Fig. 3 is shown the negative correlation $\mathrm{R} 2=0.299$ ) between $P$. ramosa emerged shoots and marketable yield is reported.

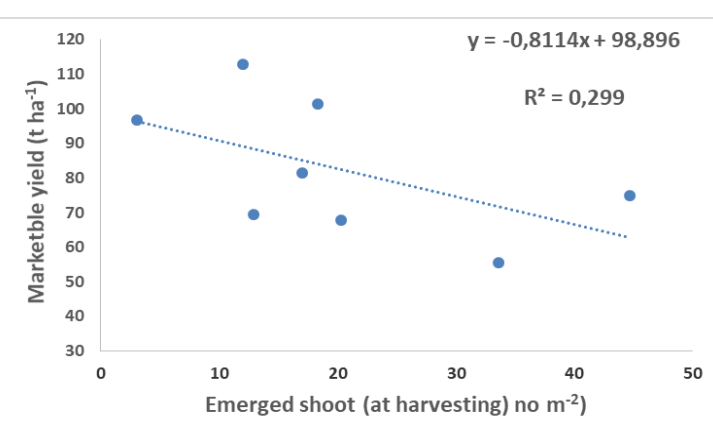

Fig. 3. Relationship between tomato marketable yield and number of emerged shoots of $P$. ramosa detected at the end of tomato cycle (harvesting time) in each trial.

\section{DISCUSSION}

In the several trials carried out in this study, the OMW treatment showed a significant reduced number of emerged $P$. ramosa plant (with values ranged between 34 and 76\%) respect to the untreated control, limiting the additional seed production of this parasite. Many studies [35] reported that the containment of infested areas and prevention of seed distribution should be major objectives of parasitic weed management strategies. This should be achieved through the prevention of seed distribution along with the direct control interventions against the parasite. The significant reduction of the $P$. ramosa emerged shoots in the OMW treated tomato crop, could be due to the organic and mineral compounds, as nitrogen, phosphorus and potassium contained in the OMW, that could improve the nutrient status of the tomato plants in addition to the effects of phenols present in the OMW that could produce a reduction of $P$. ramosa seed germination. This agrees with earlier studies which reported that mineral nutrients, organic matter and phenols introduced into the crop rhizosphere can promote severe physiological disorders for the germination of $P$. ramosa seeds, with reductions in the number and developing tubercles [16]-[29], [36], [37].

Some differences in the time of $P$. ramosa attack and shoots density obtained among years are likely linked to the different environmental conditions before transplant and during the crop cycle. Indeed, seeds of parasitic plant only germinate in response to germination stimulants (strigolactones) present in the exudates from host roots [38], [39] and to the release from dormancy following a period (conditioning) of wet conditions and optimal temperature of $20{ }^{\circ} \mathrm{C}$, immediately before germination [40].

Moreover, the mean numbers of emerged $P$. ramosa shoots, although with differences among experiments and between treated and untreated plots, increased slower in the last period of the tomato cycles, because the high temperature values that occurred in this period could induces in a secondary dormancy of parasitic seeds.

The results show the significant higher tomato marketable yield in the OMW treated crop than that in untreated crop, where higher $P$. ramosa infestation was registered. The higher yield obtained in the trial 4 compared with the other trials was probably due to the earlier transplant data (April 10, 2017) of the tomato crop.

For the fruit characteristics, such as mean fruit weight, dry matter, color index, $\mathrm{pH}$ and soluble solids content there were no significant differences between OMW treatment and the control. These results disagree with a previous research performed on tomato [41], in which, however, the $P$. ramosa infestation was much higher (108-209 shoots per host plant) than that recorded in our trials (maximum value of 40 shoots per host plant) (data not shown).

\section{CONCLUSION}

In view of the importance of processing tomato as a major cash crop for farmers, and the heavy losses in the field mainly due to Phelipanche ramosa infestation in the Apulia region (southern Italy), it is very important to control this harmful weed. Thus, the search for sustainable methods to contain this parasite has become increasingly important.

The conclusion to be drawn from the present study is that the olive-mill wastewater (OMW) incorporated into the soil at the dose of $80 \mathrm{~m} 3 \mathrm{ha}^{-1}$ (amount permitted by Italian Law No 574, 1996), 40 days prior to tomato seedling transplant, appears to be effective for the reduction of the infestation of $P$. ramosa in this crop. Moreover, the above OMW spreading amount on suitable soils can have a generally positive effect on soil and crops [42]. However, considering that this technique does not provide a complete control of the parasite it is assumed that the positive effect can be improved by combining this treatment with other, especially with the aim of gradual and continuing reduction of the "seed bank" of the parasite in the soil. Therefore, many studies are still 
necessary in order to increase knowledge about the OMW specific use for $P$. ramosa control in processing tomato crops.

\section{CONFLICT OF INTEREST}

The authors declare no conflict of interest.

\section{AUTHOR CONTRIBUTIONS}

GFL, conducted the research; GD, AT, AC analyzed the data; GD, FL, LF, wrote the paper; supervision GD; all authors had approved the final version.

\section{REFERENCES}

[1] ISTAT. (2019). Electronic information system on agriculture and livestock. Italian National Statistical Institute, Rome. [Online] Available: http://agri.istat.it/5.

[2] H. Eizemberg, N. Tanaami, B. Ovdat, and J. Rubin, "Effect of seasonal conditions host-parasite relationship in Orobanche crenata and $O$. aegyptiacal," pp. 187-193, 1998.

[3] G. Disciglio et al., "Linee Guida nel Controllo di Orobanche (Phelipanche ramosa L. Pomel) in pomodoro da industria. Nell'ambito del Progetto di ricerca "Studio e sperimentazione di mezzi innovativi di lotta nel contenimento di ORObanche ramosa quale Fanerogama parassita emergente del POMOdoro in Puglia, mediante pratiche sostenibili, come l'impiego di acque di VEGetazione"," Dipartimento di Scienze Agrarie, degli Alimenti e dell'Ambiente - Università di Foggia, pp. 1-127, ISBN 978-88-940544-3-9, 2019.

[4] B. E. Abu-Irmaileh, "Response of hemp broomrape (Orobanche ramosa) infestation to some nitrogenous compounds," Weed Sci., vol. 29, pp. 8-10, 1981

[5] K. H. Linke, J. Sauerborn, and M.C. Saxena, "Study on viability and longevity of Orobanche seed under laboratory conditions," Progress in Orobanche Research, Eberhard-Karls_Universitat, Tubingen, FRG, pp 110-114, 1989.

[6] R. Zindahl, Fundamentals of Weed Science, Academic Press Inc., New York, NY, USA, p. 499, 1993.

[7] D. Schroeder, "Potential for biological control of Cuscuta spp. and Orobanche spp," Orobanche and Cuscuta Parasitic Weed Management in the Near East, pp. 45-69, 1994.

[8] D. Rubiales, M. Ferandez-Aparicio, K. Wegmann, and D. M. Joel, "Revisiting strategies for reducing the seed bank of Orobanche and Phelipanche spp.,"Weed Res., vol. 49, pp. 23-33, 2009.

[9] S. Habimana, K. N. K. Murthy, V. Hatti, and A. Nduwumuremyi, "Management of Orobanche in field crops. A review," Scientific Journal of Crop Science, vol. 2, no. 11, pp. 144-158, 2013.

[10] G. Disciglio et al., "Effects of different methods to control the parasitic weed Phelipanche ramosa (L.) Pomel in processing tomato crops," Ital. J. Agron., vol. 11, no. 681, pp. 39-46, 2016.

[11] M. Liebman and A. S. Davis, "Integration of soil, crop and weed management in low-external-input farming systems," Weed Research, vol. 40, pp. 27-47, 2000.

[12] M. Vurro et al., "Exogenous aminoacids inhibit seed germination and tubercle formation by Orobanche ramosa (Brooomrape): Potential application for management of parasitic weed," Biol. Control, vol. 36 , pp. 258-265, 2009.

[13] M. A. Haidar and M. M. Sidahmad, "Elemental sulphur and chicken manure for the control of branched broomrape (Orobanche ramosa), Crop Prot., vol. 25, pp. 47-51, 2006.

[14] A. M. Litterick et al., "The role of un composted materials, composts, manures and compost extracts in reducing pest and disease incidence and severity in sustainable temperate agricultural and horticultural crop production. A review," Crit. Rev. Plant Sci., vol. 23, pp. 453-479, ISSN 0735-2689, 2004.

[15] R. Jain and C. L. Foy, "Nutrient effects on parasitism and germination of Egyptian broomrape (Orobanche aegyptiaca),"Weed Technology, vol. 6, pp. 269-275, 1992.

[16] K. Onekama et al., "Nitrogen deficiency as well as phosphorus deficiency in sorghum promotes the production and exudation of 5-deoxystrigol, the host recognition signal for arbuscular mycorrhizal fungi and root parasites," Planta, vol. 227, pp. 125-132, 2007.

[17] B. E. Abu-Irmaileh, "Nitrogen reduces branched broomrape (Orobanche ramosa) seed germination," Weed Science, vol. 42, 57-60, 1994.
[18] N. A. Gworgwor and H. C. Weber, "Effect on N-application on sorghum growth, Striga infestation and the osmotic pressure of the parasite in relation to the host," Journal Plant Physiology, vol. 139, pp. 194-198, 1991.

[19] J. Sauerborn, B. Kranz, and H. Mercer-Quarshie, "Organic amendments to mitigate heterotrophic weed population in savannah agriculture," Applied Soil Ecology, vol. 23, pp. 181-186, 2003.

[20] K. Simpson, Fertilizer and Manures, Longman Group Ltd, London and New York, p. 245, 1986.

[21] G. Disciglio et al., "Effects of irrigation with treated agro-industrial wastewater on soil chemical characteristics and fungal populations during processing tomato crop cycle," J. Soil Sci. Plant Nutr., vol. 15 , no. 3 , pp. $765-780,2015$.

[22] G. Disciglio et al., "Effect of olive-mill wastewater application, organo-mineral fertilization and traspanting date on the control of Phelipanche ramosa in open field processing tomato crop," Agronomy, vol. 8, no. 6, p. 92, 2018.

[23] Italian Law (Legge 11 novembre 1996 n. 574). (1996). Nuove norme in materia di utilizzazione agronomica delle acque di vegetazione e di scarichi dei frantoi oleari. Gazzetta Ufficiale. [Online]. Available: http://www.camera.it/parlam/leggi/96574.1.htm

[24] E. Bonari et al., "Spargimento delle acque di vegetazione dei frantoi oleari su terreno agrario," L'Informatore Agrario, vol. 50, suppl. 1, pp. 13-18, 2001.

[25] E. Tarantino, G. Disciglio, and A. Tarantino, "Utilizzo agronomico delle acque reflue di frantoio," Atti del convegno, Innovazione Tecnologica e Qualità dell'Olio Extravergine di Oliva, Foggia, 2003.

[26] U. Tomati and E. Galli, "The fertilizing value of wastewater from the olive processing industry," Humus, Its Structure and Role in Agriculture and Environment, Elsevier, Barking, pp. 117-126, 1992.

[27] B. Zenjari and A. Nejmeddine, "Impact of spreading olive mill wastewater on soil characteristics: laboratory experiments," Agronomie, EDP Sciences, vol. 21, no. 8, 749-755, 2001.

[28] L. Martirani et al., "Reduction of phenol content and toxicity in olive oil mill wastewaters with the ligninolytic fungus Pleurotus ostreatus," Water Res., vol. 130, pp. 1914-1918, 1996.

[29] H. Saad et al., "Land spreading of olive-mill wastewater. Effects on soil microbial activity and potential phytotoxicity," Chemosphere, vol. 66, pp. 75-83, 2007.

[30] G. Alfano et al., "Characterization of composted olive-mill wastes to predict potential plant disease suppressiveness," Biol. Control, vol. 58, pp. 199-207, 2011

[31] A. Caliandro et al., "Caratterizzazione agro-ecologica della Regione Puglia in funzione della potenzialità produttiva," Progetto ACLA, Ideaprint, BARI, 1-179, Italy, ISBN: 2-85352-339-X, 2005.

[32] AOAC, "Official method of analysis (No 934, 06)," Association of Official Analytical Chemists (AOAC), Washington, DC, USA, 1990.

[33] F. J. Francis and F. M. Clydesdale, Food Colorimetry: Theory and Applications, AVI Publ. Co., Westport, CT., p. 477, 1975.

[34] G. Gatta et al., "Effect of treated agro-industrial wastewater irrigation on tomato processing quality," Ital. J. Agron., vol. 10, pp. 97-100, 2015.

[35] Y. Goldwasser and J. Rodenburg, "Integrated agronomic management of parasitic weed seed bank. In Parasitic Orobanchacee," Parasitic Mechanisms on Control Strategies, p.497, 2013.

[36] M. Jamil et al., "Striga hermonthica parasitum in maize in response to N and P fertilizers," Field Crop Res., vol. 143, pp. 1-10, 2012.

[37] J. H. Westwood and C. L. Foy, "Influence of nitrogen on germination and early development of broomrape (Orobanche spp.)," Weed Sci., vol. 47, pp. 2-7, 1999.

[38] D. M. Joel et al., "Germination of weedy root parasites," Seed Development and Germination, pp. 567-597, MarcEl DEkker, NEW York, USA, 1995.

[39] G. N. Dhanapal et al., "Management of broomrape (Orobanche spp.) a review," Journal of Agronomy and Crop Science, Zeitschrift für Acker und Pflanzenbau, vol. 176, pp. 335-59, 1996.

[40] A. J. Murdoch and E. Kebreab, "Temperature dependence of Orobanche germination and implication for the northward spread of Orobanche within Europe," COST Action 849, Newe-Yaar Research Center, Israel, pp. 15-16, 2005.

[41] A. M. C. Longo, A. Lomonaco, and G. Mauromincale, "The effect of Phelipanche ramosa infection on the quality of tomato fruit," Weed Res., vol. 50, pp. 58-66, 2010.

[42] E. Tarantino and G. Disciglio, "Agronomic utilization of olive mill wastewater. In Olives, virgin olive oil and olive mill waste water: Sustainable management and development," in Proc. Crossborder Conference, Greece- Italy, pp. 30-32, 2012. 
Copyright $\odot 2021$ by the authors. This is an open access article distributed under the Creative Commons Attribution License which permits unrestricted use, distribution, and reproduction in any medium, provided the original

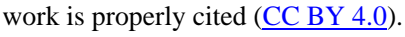

Grazia Disciglio is a researcher in agronomy and herbaceous crop at the Department Agriculture Food Natural Science Engineering, University of Foggia, Foggia, Italy. Training and experience in scientific and/or professional: Member of the Master's project "Organic Farming", management of the Master Manager "Organic Farming"-POR Puglia 2000-2006. In 2010 participates in the project "Feasibility study for the use of treated wastewater in the industrial district - ASI Consortium - Foggia". Since 2012 participate in the project PON In.Te.RRA "Technological innovations and process for the reuse of urban waste water and agro-industrial products for the sustainable management of water resources. Since 2016 he participated in the research and experimentation project entitled "Study and experimentation of innovative means of struggle in the containment of Orobanche ramosa as an emerging parasitic phanerogama of tomatoes in Puglia region, through sustainable practices such as the use of vegetation waters". "Use of natural bio-organic substances (SBN) as biostimulants on tomato and pomegranate crops". She was involved in numerous research. Her current research interests concern various topics of agronomy and herbaceous cultivation, in particular irrigation with conventional and non-conventional water (water-waste), the use of organic mineral fertilizers on herbaceous crops in conventional and organic agriculture.

Francesco Lopes is an associate professor. Francesco Lopes' research interests: plant pathology herbaceous and arboreal plant diseases and in the fight against parasites (fungi, bacteria and viruses) with sustainable methods.

Antonia Carlucci is a researcher. Antonia Carlucci's research interests: plant pathology herbaceous and arboreal plant diseases and in the fight against parasites (fungi, bacteria and viruses) with sustainable methods.

Laura Frabboni is an associate professor. Laura Frabboni has the membership of the "Società Italiana di Agronomia" (SIA). Laura Frabbon's research interests: crop physiology, aroma volatiles, crop production and management.

Annalisa Tarantino is a researcher. Annalisa Tarantino has the membership of the "International Society for Horticultural Science" (ISHS) and of the "Società Orticola Italiana" (SOI). Annalisa Tarantino's research interests: fruit set, growth, yield and fruit quality and development; biostimolant application, food 